\title{
Painful Recurrent Diplopia Caused by Medial Rectus Cysticercosis
}

Emmanuelle Moret, and François-Xavier Borruat, MD

Neurology ${ }^{\circledR}$ 2021;96:452-453. doi:10.1212/WNL.0000000000011466
Correspondence

Dr. Borruat

francois.borruat@fa2.ch

Figure Orbital MRI: Left Medial Rectus Cysticercosis
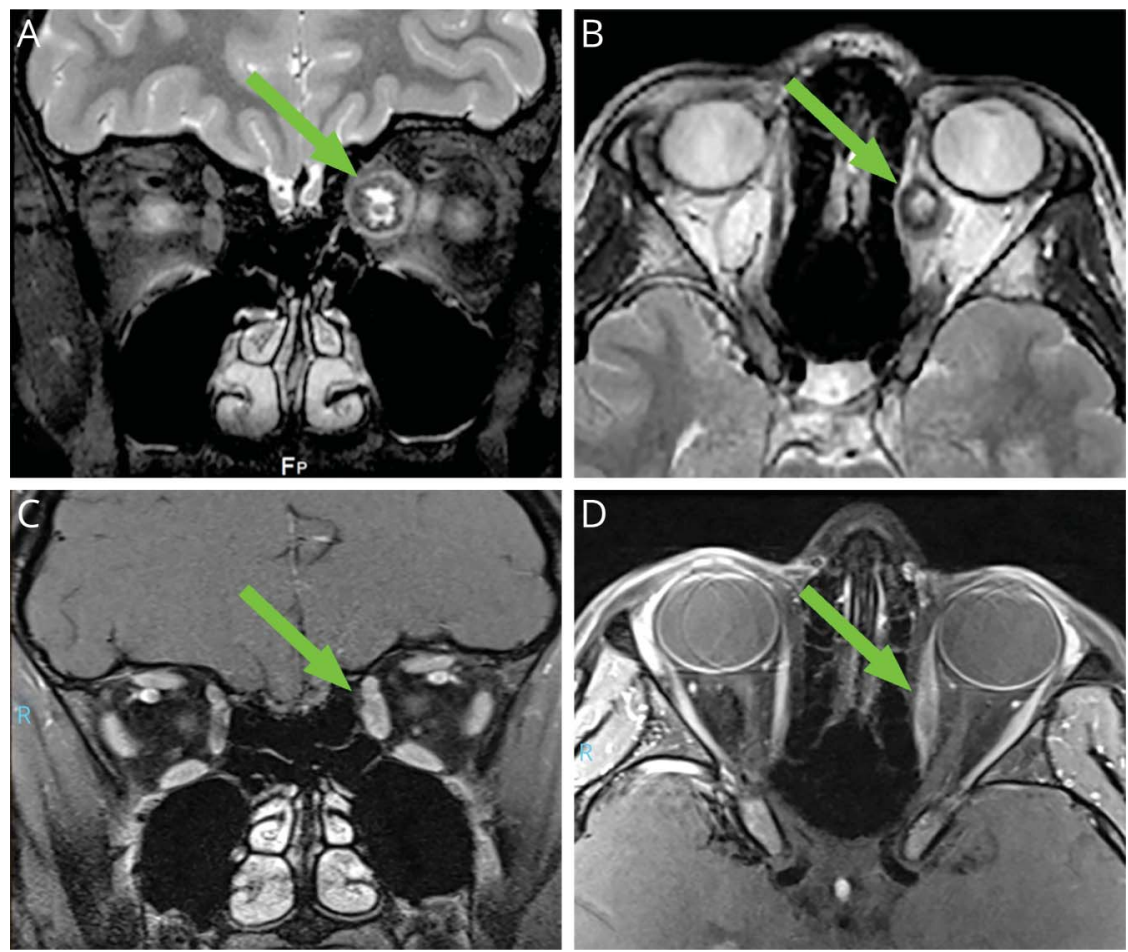

Orbital MRI, coronal (A) and axial (B) T2-weighted sequences. A single intrinsic cystic lesion compatible with a cysticercus (central hypodense scolex) is visible inside the enlarged left medial rectus muscle. A total of 18 months after therapy, coronal (C) and axial gadolinium-enhanced (D) T1-weighted sequences revealed residual fibrosis of left medial rectus muscle.

A 17-year-old girl, who previously lived in South America, complained of painful diplopia for 1 month. Two similar transient episodes occurred 6 and 36 months previously. Left abduction and elevation were limited, with $2 \mathrm{~mm}$ left proptosis. Orbital MRI revealed a left medial rectus muscle cysticercus (figure). Blood serology was positive for cysticercosis. Rapid improvement followed oral albendazole and prednisone therapy.

Cysticercosis develops when humans become the intermediate host of Taenia solium, occurring mostly under poor sanitary conditions. Because of travel, cysticercosis is encountered worldwide. MRI appearance and blood serologies are diagnostic and oral albendazole is usually curative. ${ }^{1,2}$

\section{Study Funding}

No targeted funding reported. 


\section{Disclosures}

The authors report no disclosures relevant to the manuscript. Go to Neurology.org/N for full disclosures.

Appendix Authors

\begin{tabular}{lll}
\hline Name & Location & Contribution \\
\hline $\begin{array}{lll}\text { Emmanuelle } \\
\text { Moret, MD }\end{array}$ & $\begin{array}{l}\text { Hôpital Ophtalmique } \\
\text { Jules-Gonin, Lausanne, } \\
\text { Switzerland }\end{array}$ & $\begin{array}{l}\text { Examined the clinical chart, } \\
\text { wrote the manuscript, } \\
\text { composed the figure }\end{array}$ \\
\hline
\end{tabular}

Appendix (continued)

\begin{tabular}{lll}
\hline Name & Location & Contribution \\
\hline $\begin{array}{l}\text { François- } \\
\text { Xavier } \\
\text { Borruat, MD }\end{array}$ & $\begin{array}{l}\text { Hôpital Ophtalmique } \\
\text { Switzerland }\end{array}$ & $\begin{array}{l}\text { Acquired the data (examined } \\
\text { the patient, established the } \\
\text { diagnosis), revised the } \\
\text { manuscript }\end{array}$ \\
\hline
\end{tabular}

\section{References}

1. Garcia HH, Nash TE, Del Brutto OH. Clinical symptoms, diagnosis, and treatment of neurocysticercosis. Lancet Neurol 2014;13:1202-1215.

2. Ziaei M, Elgohary M, Bremner FD. Orbital cysticercosis, case report and review. Orbit 2011;30:230-235.

\section{Disputes \& Debates: Rapid online correspondence}

The editors encourage comments on recent articles through Disputes \& Debates:

Access an article at Neurology.org/N and click on "MAKE COMMENT" beneath the article header. Responses will be posted as rapidly as possible.

Before submitting a comment to Disputes \& Debates, remember the following:

- Disputes \& Debates is restricted to comments about articles published in Neurology within the last 8 weeks

- Read previously posted comments; redundant comments will not be posted

- Your submission must be 200 words or less and have a maximum of 5 references; the first reference must be the article on which you are commenting

- You can include a maximum of 5 authors (including yourself)

\section{Sign Up for the AAN's Axon Registry}

The AAN encourages its US members to show their interest in participating in the Axon Registry by signing up today.

Use the Axon Registry to:

- Simplify reporting requirements under MACRA's Quality Payment Program and avoid penalties while reducing your administrative burden

- Meet your MOC Part IV requirements and waive up to eight credits of Part II Self-Assessment

- Choose from 22 AAN neurology-specific quality measures that fit your practice

- Use data to understand your practice and identify where improvements can be made to patient care

- Manage your patients at a population level; look at a specific group of patients based on conditions, risk factors, demographics or outcome

- Demonstrate your value to payers when negotiating reimbursement

- Enjoy multi-year, fee-free access when you sign the agreements and integrate your EHR with the registry

Learn more at AAN.com/view/Axon and send your questions to registry@aan.com. 


\title{
Neurology
}

\author{
Painful Recurrent Diplopia Caused by Medial Rectus Cysticercosis \\ Emmanuelle Moret and François-Xavier Borruat \\ Neurology 2021;96;452-453 Published Online before print January 6, 2021 \\ DOI 10.1212/WNL.0000000000011466
}

This information is current as of January 6, 2021

$\begin{array}{ll}\begin{array}{l}\text { Updated Information \& } \\ \text { Services }\end{array} & \begin{array}{l}\text { including high resolution figures, can be found at: } \\ \text { http://n.neurology.org/content/96/9/452.full }\end{array} \\ \text { References } & \text { This article cites } 2 \text { articles, } 0 \text { of which you can access for free at: } \\ & \text { http://n.neurology.org/content/96/9/452.full\#ref-list-1 } \\ \text { Subspecialty Collections } & \text { This article, along with others on similar topics, appears in the } \\ & \text { following collection(s): } \\ & \text { Diplopia (double vision) } \\ & \text { http://n.neurology.org/cgi/collection/diplopia_double_vision } \\ & \text { Ocular motility } \\ & \text { http://n.neurology.org/cgi/collection/ocular_motility } \\ \text { Orbit } & \text { http://n.neurology.org/cgi/collection/orbit } \\ & \text { Parasitic infections } \\ & \text { http://n.neurology.org/cgi/collection/parasitic_infections } \\ & \text { Information about reproducing this article in parts (figures,tables) or in } \\ & \text { its entirety can be found online at: } \\ & \text { http://www.neurology.org/about/about_the_journal\#permissions } \\ & \text { Information about ordering reprints can be found online: } \\ \text { Pttp://n.neurology.org/subscribers/advertise }\end{array}$

Neurology ${ }^{\circledR}$ is the official journal of the American Academy of Neurology. Published continuously since 1951, it is now a weekly with 48 issues per year. Copyright (C 2021 American Academy of Neurology. All rights reserved. Print ISSN: 0028-3878. Online ISSN: 1526-632X.

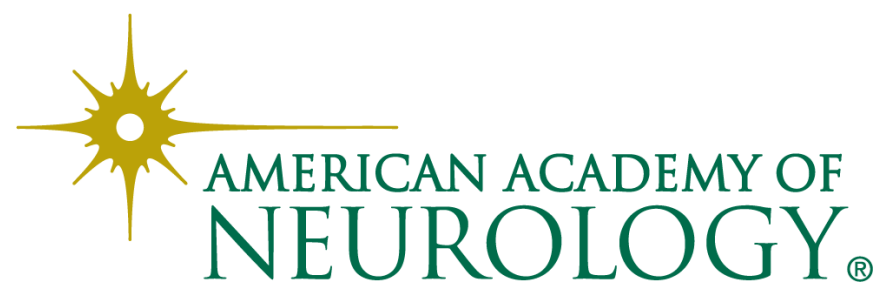

